\title{
C-type natriuretic peptide chronic administration attenuates cardiac fibrosis and inflammation in spontaneously hypertensive rats
}

\author{
E Santos Prentki ${ }^{1 *}$, C Caniffi ${ }^{1}$, G Bouchet ${ }^{1}$, D Maglio González ${ }^{2}$, J Toblli ${ }^{3}$, MA Costa ${ }^{1}$, C Arranz ${ }^{1}$ \\ From 7th International Conference on cGMP Generators, Effectors and Therapeutic Implications \\ Trier, Germany. 19-21 June 2015
}

\section{Background}

Growing evidence shows that the expression and release of a number of inflammatory cytokines are increased in hypertension [1,2] and are also present at sites of cardiovascular fibrosis. In fact, many of these inflammatory mediators are responsible for the activation of collagen producing fibroblasts [3]. In addition, proinflammatory cytokines such as tumor necrosis factor-alpha (TNF- $\alpha$ ) and interleukin-1 (IL-1) have shown to stimulate the release of C-type natriuretic peptide (CNP), indicating a potential role of CNP as a modulator of the inflammatory process [4]. The aim of the present study was to evaluate the effects of chronic CNP treatment on cardiac fibrosis and inflammation in spontaneously hypertensive rats (SHR).

\section{Experimental design and methods}

12-week-old male SHR and Wistar rats were infused through osmotic pumps with CNP $(0,75 \mu \mathrm{g} / \mathrm{hr})$ or saline (S) for 14 days. Systolic blood pressure (SBP, $\mathrm{mmHg}$ ) was recorded by tail-cuff method. At the end of the treatment, the left ventricle (LV) was extracted to determine left ventricular mass index (LVMI, g LV/mm tibia length), the myocyte area $\left(\mu \mathrm{m}^{2}\right.$, Haematoxylin and Eosin-stain), fibrosis (\% collagen, Picrosirius Red stain) and inflammation parameters (IL- 6 and TNF- $\alpha, \%$ stain $/ \mathrm{mm}^{2}$ by immunohistochemistry, IHC and IL- 6 , TNF- $\alpha$ and IL- $1 \beta, \mathrm{pg} / \mathrm{mg}$ protein by ELISA).

\section{Results}

Table 1

\begin{tabular}{|c|c|c|c|c|}
\hline & W-S & W-CNP & SHR-S & SHR-CNP \\
\hline SBP & $118 \pm 2$ & $122 \pm 3$ & $175 \pm 3^{*}$ & $159 \pm 5 \#$ \\
\hline LMVI & $0,023 \pm 0,002$ & $0,024 \pm 0,001$ & $0,032 \pm 0,001^{*}$ & $0,029 \pm 0,001$ \\
\hline Myocyte area & $349 \pm 11$ & $337 \pm 10$ & $609 \pm 25^{*}$ & $557 \pm 35 \#$ \\
\hline$\%$ Fibrosis & $1,54 \pm 0,53$ & $1,78 \pm 0,17$ & $6,81 \pm 0,40^{*}$ & $3,27 \pm 0,67 \#$ \\
\hline IL-6 (IHC) & $1,8 \pm 1,0$ & $1,3 \pm 0,6$ & $19,4 \pm 2,7^{*}$ & $2,1 \pm 0,7 \#$ \\
\hline TNF- $\alpha(\mathrm{IHC})$ & $1,1 \pm 0,7$ & $1,0 \pm 0,5$ & $15,7 \pm 3,4^{*}$ & $1,5 \pm 0,9 \#$ \\
\hline IL-6 (ELISA) & - & - & $100,1 \pm 6,2$ & $81,0 \pm 9,0$ \\
\hline TNF- $\alpha$ (ELISA) & - & - & $8,27 \pm 0,89$ & $4,32 \pm 0,18 \#$ \\
\hline $\mathbb{L L}-1 \beta(E L I S A)$ & - & - & $135,7 \pm 5,8$ & $120,3 \pm 2,3 \#$ \\
\hline
\end{tabular}

\section{Conclusions}

Characteristic high SBP values in SHR are accompanied by hypertrophy, fibrosis and a higher presence of inflammatory cytokines.

Our results show that chronic treatment with CNP attenuates the expression of proinflammatory markers and the early signs of fibrosis in cardiac tissue of hypertensive rats. These effects, combined with the drop in blood pressure we observed, indicate that CNP could possibly have an important pathophysiological and therapeutical role in preventing or even reversing cardiac fibrosis and inflammation accompanying left ventricular remodelling in arterial hypertension.

\footnotetext{
Authors' details

${ }^{1}$ Physiology, School of Pharmacy and Biochemistry, IQUIMEFA-CONICET, University of Buenos Aires, Argentina. ${ }^{2}$ Immunology, School of Pharmacy
}

\footnotetext{
* Correspondence: eprentki@ffyb.uba.ar

'Physiology, School of Pharmacy and Biochemistry, IQUIMEFA-CONICET, University of Buenos Aires, Argentina

Full list of author information is available at the end of the article
} 
and Biochemistry, IDEHU-CONICET, University of Buenos Aires, Argentina. ${ }^{3}$ Laboratory of Experimental Medicine, German Hospital, Buenos Aires,

Argentina.

Published: 2 September 2015

\section{References}

1. Sanz-Rosa D, Oubiña MP, Cediel E, de Las Heras N, Vegazo O, Jiménez J, Lahera V, Cachofeiro V: Effect of AT1 receptor antagonism on vascular and circulating inflammatory mediators in SHR: role of NF-kappaB/ IkappaB system. Am J Physiol Heart Circ Physiol 2005, 288:H111-H115.

2. Dinh QN, Drummond GR, Sobey CG, Chrissobolis S: Roles of inflammation, oxidative stress, and vascular dysfunction in hypertension. Biomed Res Int 2014, 2014:406960.

3. Lee SB, Kalluri R: Mechanistic connection between inflammation and fibrosis. Kidney Int Suppl 2010, 119:S22-S26.

4. Osterbur K1, Yu DH, DeClue AE: Interleukin-1 $\beta$, tumour necrosis factor-a and lipopolysaccharide induce C-type natriuretic peptide from canine aortic endothelial cells. Res Vet Sci 2013, 94:478-83.

doi:10.1186/2050-6511-16-S1-A104

Cite this article as: Prentki et al:: C-type natriuretic peptide chronic

administration attenuates cardiac fibrosis and inflammation in

spontaneously hypertensive rats. BMC Pharmacology and Toxicology 2015

16(Suppl 1):A104.

\section{Submit your next manuscript to BioMed Central} and take full advantage of:

- Convenient online submission

- Thorough peer review

- No space constraints or color figure charges

- Immediate publication on acceptance

- Inclusion in PubMed, CAS, Scopus and Google Scholar

- Research which is freely available for redistribution

Submit your manuscript at www.biomedcentral.com/submit 